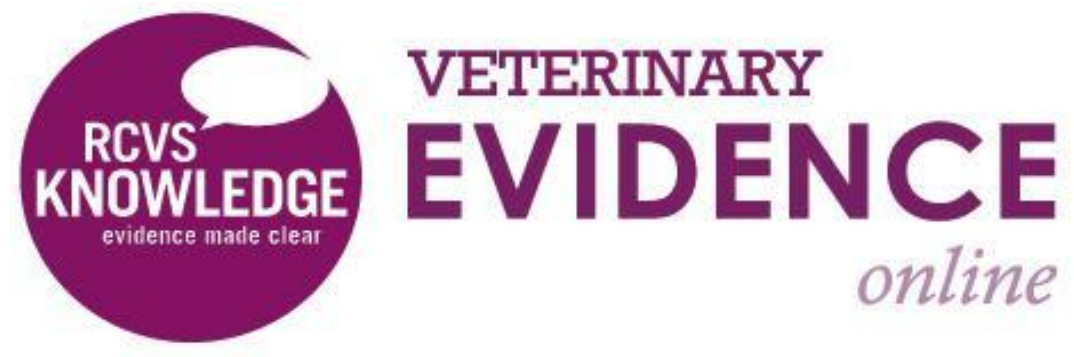

\title{
Is there enough evidence to recommend surgical treatment as opposed to conservative treatment for dogs affected by bicipital tenosynovitis?
}

A Knowledge Summary by

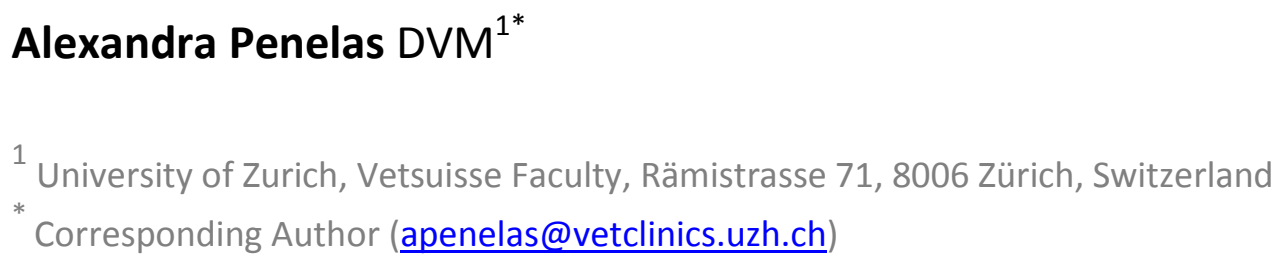

ISSN: 2396-9776

Published: 20 May 2016

in: Vol 1, Issue 2

DOI: http://dx.doi.org/10.18849/ve.v1i2.29

Reviewed by: Bruce Smith (BVSc MS FANZCVS DACVS) 


\section{KNOWLEDGE SUMMARY}

\section{Clinical bottom line}

There is currently insufficient evidence to conclude that tenotomy or tenodesis has a better outcome compared to conservative treatment in cases of canine bicipital tenosynovitis.

\section{Question}

Is surgical treatment with tenotomy or tenodesis superior to conservative treatment for canine bicipital tenosynovitis?

\section{The evidence}

There is insufficient evidence for clinical decision-making regarding recommendation of surgical treatment versus conservative treatment.

\section{Summary of the evidence}

Bruce, W.J. et al. (2000)

\begin{tabular}{|c|c|}
\hline Population: & $\begin{array}{l}\text { Dogs with bicipital tendinitis, lame with pain localised to the biceps } \\
\text { tendon, definitive diagnosis was established on the basis of clinical, } \\
\text { sonographic and radiographic findings, synovial-fluid analysis. }\end{array}$ \\
\hline Sample size: & 15 dogs $n=15$ \\
\hline Intervention details: & $\begin{array}{l}13 \text { dogs initially underwent conservative treatment with rest (cage } \\
\text { or small room and only short walks on a leash for six weeks and after } \\
\text { improvement controlled walks on a leash for six weeks, followed by } \\
\text { gradual return to normal exercise level) together with } 2 \text { to } 4 \mathrm{mg} / \mathrm{kg} \\
\text { daily carprofen for } 2 \text { or } 3 \text { weeks or a single peri-tendinous injection } \\
\text { of } 20 \text { to } 40 \mathrm{mg} \text { of Methylprednisolone acetate and rest. Surgical } \\
\text { treatment was done in } 3 \text { cases, } 1 \text { case that failed to improve after } \\
\text { conservative treatment was treated by tenodesis and } 2 \text { additional } \\
\text { cases were treated by either tenodesis or tenolysis. }\end{array}$ \\
\hline Study design: & Non-comparative study (case series). \\
\hline Outcome studied: & $\begin{array}{l}\text { Subjective: Re-examination by the authors at six weeks by lameness } \\
\text { and shoulder assessment, sonography was done in } 4 \text { dogs, long-term } \\
\text { follow-up was obtained by a telephone interview of the owners' } \\
\text { assessment and outcome was classified as excellent (never lame), } \\
\text { good (only lame after heavy activity), fair (lame after moderate or } \\
\text { normal activity) or poor (always lame, no improvement) according } \\
\text { owners' assessment. }\end{array}$ \\
\hline
\end{tabular}




\begin{tabular}{|c|c|}
\hline $\begin{array}{l}\text { Main findings: } \\
\text { (relevant to PICO question): }\end{array}$ & $\begin{array}{l}\text { Sonography was considered to be more sensitive by the authors } \\
\text { than radiography or arthrography in characterising the lesion. } \\
\text { Conservative treatment resulted in good to excellent long-term } \\
\text { results in } 11 \text { cases. In the } 3 \text { surgically treated cases the case which } \\
\text { didn't improve after conservative treatment also didn't improve } \\
\text { after surgery, another case improved and } 1 \text { case which didn't } \\
\text { improve had the diagnosis osteosarcoma in the follow-up time. } 10 \text { of } \\
11 \text { dogs treated conservatively showed improvement at a six-week } \\
\text { follow-up. Time to resolve the lameness ranged from } 2 \text { weeks up to } \\
\text { seven months. }\end{array}$ \\
\hline Limitations: & $\begin{array}{l}\text { A comparison between different treatments was not possible due to } \\
\text { a lack of randomised treatment groups. Only subjective assessment } \\
\text { of treatment effect and therefore only a moderate rating about } \\
\text { conservative versus surgical therapy can be made. }\end{array}$ \\
\hline \multicolumn{2}{|l|}{ Wall, C.R. et al. (2002) } \\
\hline Population: & $\begin{array}{l}\text { Diagnosis was based on clinical examination and diagnostic imaging, } \\
\text { if conservative treatment ( } 1 \text { or } 2 \text { times intra-articular injection of } \\
\text { long-acting corticosteroids) failed, surgery was performed. }\end{array}$ \\
\hline Sample size: & $\begin{array}{l}5 \text { dogs } \\
n=5\end{array}$ \\
\hline Intervention details: & $\begin{array}{l}\text { Initial treatment included intra-articular injection of } 1.0 \mathrm{mg} \\
\text { Triamcinolone acetonide and exercise restriction in } 4 \text { dogs and a } \\
\text { tapering dose of carprofen with exercise restriction in } 1 \mathrm{dog} \text {. If the } \\
\text { dog didn't respond to conservative treatment or after recurrence a } \\
\text { bipolar radiofrequency electrosurgical system was used for } \\
\text { arthroscopic transection of the bicipital tendon. }\end{array}$ \\
\hline Study design: & Non-comparative study (case series) \\
\hline Outcome studied: & $\begin{array}{l}\text { Subjective revaluation } 2 \text { weeks after surgery which included a walk, } \\
\text { follow-up } 2 \text { and } 6 \text { months following surgery which included gait at } \\
\text { walk and trot, shoulder range of motion and pain assessment with } \\
\text { palpation and shoulder movement. Owner questioned regarding } \\
\text { activity level and use of NSAIDs, results were placed into an objective } \\
\text { rating scale and were assigned a rating of excellent, good, fair or } \\
\text { poor. }\end{array}$ \\
\hline $\begin{array}{l}\text { Main findings: } \\
\text { (relevant to PICO question): }\end{array}$ & $\begin{array}{l}\text { Outcome after surgery of } 4 \text { dogs were rated as excellent and in } 1 \\
\text { dog as good. }\end{array}$ \\
\hline Limitations: & $\begin{array}{l}\text { Subjective assessment of treatment outcome, no control group or } \\
\text { different treatment groups for comparison, limited case number. }\end{array}$ \\
\hline \multicolumn{2}{|l|}{ Stobie, D. et al. (1995) } \\
\hline Population: & $\begin{array}{l}\text { Medical records from } 1985 \text { to } 1992 \text { of dogs with bicipital } \\
\text { tenosynovitis, for medical treated cases where the diagnosis was } \\
\text { based on clinical examination and radiographic features of bicipital } \\
\text { tenovaginitis. For surgical cases the diagnosis has to be additionally }\end{array}$ \\
\hline
\end{tabular}




\begin{tabular}{|c|c|}
\hline & $\begin{array}{l}\text { confirmed by histology, owners had to be available for follow-up } \\
\text { information in all cases, additional arthrogramm was done in } 12 \\
\text { cases and arthrocentesis in } 17 \text { cases. }\end{array}$ \\
\hline Sample size: & $\begin{array}{l}26 \text { dogs (29 shoulders) } \\
n=26\end{array}$ \\
\hline Intervention details: & $\begin{array}{l}21 \text { of } 29 \text { shoulder joints were treated conservatively with } \\
\text { methylprednisolone acetate injections (if no improvement was } \\
\text { observed injection was repeated after } 2 \text { weeks, number of injection } \\
\text { ranged from } 1 \text { to } 3 \text { ) and restricting exercise of } 2 \text { weeks (restriciting } \\
\text { exercise was not precisely defined). If lameness didn't improve } \\
\text { injections were repeated at 2-week intervals (maximal } 3 \text { times). } 14 \\
\text { cases underwent tenodesis of the biceps tendon and exercise } \\
\text { restriction for } 6 \text { to } 8 \text { weeks (restricting exercise was not precisely } \\
\text { defined) following surgery ( } 6 \text { of them had poor results after medical } \\
\text { treatment and therefore underwent surgery). }\end{array}$ \\
\hline Study design: & Retrospective case series \\
\hline Outcome studied: & $\begin{array}{l}\text { Efficacy of treatment was determined at the last physical } \\
\text { examination and rated as excellent, good, fair or poor according to } \\
\text { gait, limb function, range of motion and signs of pain. Results were } \\
\text { also assessed on follow-up information from the owners regarding } \\
\text { activity level, degree of lameness, need of anti-inflammatory drugs } \\
\text { and ability to work. Results were considered to be excellent (never } \\
\text { lame), good (only lame after heavy activity), fair (lame after } \\
\text { moderate activity) and poor (always lame). } 17 \text { conservative treated } \\
\text { cases and } 12 \text { of the surgically treated cases were available for clinical } \\
\text { evaluation. }\end{array}$ \\
\hline $\begin{array}{r}\text { Main findings: } \\
\text { (relevant to PICO question): }\end{array}$ & $\begin{array}{l}\text { Of } 17 \text { conservative treated cases } 3 \text { were rated as excellent, } 4 \text { as } \\
\text { good, } 4 \text { as fair and } 6 \text { as poor in the clinical revaluation. } 8 \text { of } 12 \\
\text { clinical available surgically treated cases were rated as excellent and } \\
4 \text { as good. Owners reported excellent results in } 3 \text {, good results in } 7 \text {, } \\
\text { fair results for } 5 \text { and poor for } 6 \text { of } 21 \text { medically treated cases. Of } 14 \\
\text { surgically treated cases } 11 \text { were rated as excellent and } 3 \text { as good. } \\
\text { Time to achieve good or excellent clinical results after surgery } \\
\text { ranged from } 2 \text { to } 9 \text { months. }\end{array}$ \\
\hline Limitations: & $\begin{array}{l}\text { Retrospective study and therefore not randomized control study, } \\
\text { only subjective assessment. Seventeen of } 21 \text { medically treated } \\
\text { shoulders ( } 16 \text { dogs) and twelve of } 14 \text { surgical treated shoulders (11 } \\
\text { dogs) were available for clinical reevaluation. Owner assessment } \\
\text { was available for all dogs. Lost of follow-up in some cases, low } \\
\text { number of cases. }\end{array}$ \\
\hline
\end{tabular}


The purpose of this Knowledge Summary was to look for evidence regarding different outcomes of tenotomy or tenodesis of the biceps brachii compared to non-surgical treatments in canine bicipital tenosynovitis/tenovaginitis by reviewing veterinary literature.

So far there are a few publications reporting different surgical techniques, but a real comparison between nonsurgical and surgical treatments of canine bicipital tenosynovitis is lacking in veterinary literature. Three noncomparative studies were found in the literature. All studies suffer, besides the weakness of being retrospective, in having an objective measurement of the therapy outcome. Furthermore, the diagnostic challenge of shoulder pathologies was not considered in those studies. Many shoulder diseases have similar clinical and radiographic appearances. Diagnosis of bicipital tenosynovitis was based in all mentioned studies on clinical signs and radiographs only. Therefore, other shoulder disorders cannot be definitively excluded. Furthermore, it needs to be mentioned that non-surgical therapies can have a positive effect independent of treating bicipital tenosynovitis or another shoulder disorder, as they are non-specific treatments.

In a descriptive study of 15 cases from Bruce et al. (2000) good or excellent function at long-term follow-up was recorded for 11 of 13 conservative treated cases. On the basis of only 3 surgically treated dogs a comparison between conservative and surgical treatment of bicipital tenosynovitis in that study cannot be made. In addition the clinical follow-up was made without an objective measurement and the long-term follow-up was only done by the owners. This may have influenced the promising results of conservative treatment. The only possible implication for the practice from this study is that recovery time after conservative treatment can range from 2 weeks up to 7 months. This finding, even if it's just from a case series, emphasises the importance of rest, as a considerable element of conservative treatment. The dogs were restricted to cage or small room for 6 weeks and another 6 weeks to the house of yard with controlled walks on a leash.

Another case series was published from Wall et al. (2002). All dogs initially underwent conservative treatment but because lameness remained, arthroscopic tenotomy of the biceps brachii was done in all of them. The long-term outcome after arthroscopic tenotomy was good to excellent. There is not much information from this report to conclude whether conservative or surgical therapy of bicipital tenovaginitis is better, but all dogs improved post tenotomy compared to the presurgical condition

In a retrospective study of Stobie et al. (1995) 29 cases of bicipital tenovaginitis were included. In the medical treated cases only 7 of 17 cases were clinically rated as good or excellent and owners reported good to excellent results in 10 of 21 cases. The moderate outcome of the conservative treatment in this study is opposed to the promising results of conservative treatment of Bruce et al. (2000). These conflicting results may be due to the difference in the length of prescribed rest as part of conservative therapy. All dogs, which could be evaluated clinically after tenodesis, had an outcome of excellent to good. Owners also rated the outcome of all surgically treated dogs as excellent to good. This result corresponds to the result of Wall et al. (2000) and leads to the assumption that tenodesis may be promising and a good option if conservative treatment fails.

In conclusion, there is insufficient evidence to support conservative therapy more than surgical treatment or vice versa. The only conclusion for clinical practice that can be made based on the literature is that if conservative treatment failed surgical therapy may be an option that may lead to improvement. 


\section{Methodology Section}

\begin{tabular}{|c|c|}
\hline \multicolumn{2}{|l|}{ Search Strategy } \\
\hline $\begin{array}{r}\text { Databases searched and dates } \\
\text { covered: }\end{array}$ & $\begin{array}{l}\text { The following search terms were applied to the PubMed } \\
\text { database, accessed via the NCBI website (1910-2015) and the } \\
\text { CAB abstracts database (1973-2015) accessed on the OVID } \\
\text { platform, Scopus, Web of Science, VetMed Resource }\end{array}$ \\
\hline Search terms: & $\begin{array}{l}\text { dog OR dogs OR canine OR bitch* OR dogs/ OR bitches OR canis/ } \\
\text { AND } \\
\text { biceps OR bicipital* AND tendonitis OR tendinitis OR } \\
\text { tenosynovitis OR "inflammation ADJ5 tendon*” AND } \\
\text { tenotom* OR transect* OR treat* OR manag* OR therap* OR } \\
\text { treatment/ or management/ OR therapy/ }\end{array}$ \\
\hline Dates searches performed: & January 2016 \\
\hline
\end{tabular}

\section{Exclusion / Inclusion Criteria}

Exclusion: Non-English language, reviews, case reports, conference papers

Inclusion: Studies which investigated and compared the outcome of conservative and surgical therapy in bicipital tenosynovitis

\begin{tabular}{|c|c|c|c|c|c|}
\hline \multicolumn{6}{|c|}{ Search Outcome } \\
\hline Database & $\begin{array}{l}\text { Number of } \\
\text { results }\end{array}$ & $\begin{array}{l}\text { Excluded - } \\
\text { duplicates }\end{array}$ & $\begin{array}{c}\text { Excluded - not } \\
\text { English } \\
\text { language }\end{array}$ & $\begin{array}{l}\text { Excluded - did } \\
\text { did not answer } \\
\text { the PICO } \\
\text { question }\end{array}$ & $\begin{array}{c}\text { Total relevant } \\
\text { papers }\end{array}$ \\
\hline PubMed & 16 & & & 13 & 3 \\
\hline Scopus & 26 & 2 & 3 & 25 & 1 \\
\hline $\begin{array}{l}\text { Web of } \\
\text { Science }\end{array}$ & 49 & 1 & 1 & 47 & 2 \\
\hline $\begin{array}{l}\text { CAB } \\
\text { Abstracts }\end{array}$ & 29 & & 2 & 27 & 2 \\
\hline & & & & & 3 \\
\hline
\end{tabular}

\section{CONFLICT OF INTEREST}

The author declares no conflict of interest. 


\section{REFERENCES}

1. Bruce, W. J. et al (2000) Bicipital tendinitis and tenosynovitis in the dog: a study of 15 cases. New Zealand Veterinary Journal, 48 (02), pp 44-52. http://dx.doi.org/10.1080/00480169.2000.36157

2. Stobie, D. et al (1995) Chronic bicipital tenosynovitis in dogs: 29 cases (1985-1992). Journal of American Veterinary Medical Association, 207, pp. 201-7.

3. Wall, C. R. and Taylor, R. (2002) Arthroscopic biceps brachii tenotomy as a treatment for canine bicipital tenosynovitis. Journal of the American Animal Hospital Association, 38 (2), pp. 16975. http://dx.doi.org/10.5326/0380169 


\section{EVIDENCE \\ online}

\section{Intellectual Property Rights}

Authors of Knowledge Summaries submitted to RCVS Knowledge for publication will retain copyright in their work, but will be required to grant to RCVS Knowledge an exclusive license of the rights of copyright in the materials including but not limited to the right to publish, re-publish, transmit, sell, distribute and otherwise use the materials in all languages and all media throughout the world, and to license or permit others to do so.

Authors will be required to complete a license for publication form, and will in return retain certain rights as detailed on the form.

Veterinary Evidence and EBVM Network are RCVS Knowledge initiatives. For more information please contact us at editor@veterinaryevidence.org.

RCVS Knowledge is the independent charity associated with the Royal College of Veterinary Surgeons (RCVS). Our ambition is to become a global intermediary for evidence based veterinary knowledge by providing access to information that is of immediate value to practicing veterinary professionals and directly contributes to evidence based clinical decision-making.

\section{www.veterinaryevidence.org}

RCVS Knowledge is a registered Charity No. 230886. Registered as a Company limited by guarantee in England and Wales No. 598443.

Registered Office: Belgravia House 62-64 Horseferry Road London SW1P 2AF 